\title{
Effect of ascorbic acid and hydrogen peroxide on mouse neuroblastoma cells
}

\author{
CHRISTINA M. HARDAWAY ${ }^{1}$, RAMESH B. BADISA ${ }^{2}$ and KARAM F.A. SOLIMAN ${ }^{2}$ \\ ${ }^{1}$ Meharry Medical College, Nashville, TN 37208; ${ }^{2}$ College of Pharmacy and Pharmaceutical Sciences, \\ Florida A\&M University, Tallahassee, FL 32307, USA
}

Received October 3, 2011; Accepted December 27, 2011

DOI: $10.3892 / \mathrm{mmr} .2012 .857$

\begin{abstract}
Ascorbic acid is one of the antioxidant compounds widely used against free radical stress. The present study was undertaken to examine whether ascorbic acid and hydrogen peroxide $\left(\mathrm{H}_{2} \mathrm{O}_{2}\right)$, alone or in combination, could influence cell viability. The murine neuroblastoma cell line, N2a, was used to perform a dose response curve for ascorbic acid. It was observed that ascorbic acid alone at physiological concentrations (0.1-0.4 mM) did not cause any cell death. However, at pharmacological concentrations (1-6 mM), ascorbic acid caused dose-dependent cell death. The lethal concentration at which $50 \%$ cells were killed $\left(\mathrm{LC}_{50}\right)$ was determined to be approximately $3.141 \mathrm{mM}$ ascorbic acid at $24 \mathrm{~h} . \mathrm{H}_{2} \mathrm{O}_{2}$ up to $300 \mu \mathrm{M}$ alone did not cause significant cell death. In the combined treatment, when the cells were treated with ascorbic acid at physiological concentrations $(0.4 \mathrm{mM})$ and $\mathrm{H}_{2} \mathrm{O}_{2}$ at $400 \mu \mathrm{M}$, higher rates of cell death were observed compared to the cell death rates caused by either compound alone. Subsequent experiments revealed that cell death was partly mediated through the loss of total glutathione levels in the cells. These data suggest that the combination of ascorbic acid and $\mathrm{H}_{2} \mathrm{O}_{2}$ is disadvantageous for cancer cell survival. Further studies are required to ascertain the physiological significance of these observations.
\end{abstract}

\section{Introduction}

Cancer is a major health problem that accounts for more than seven million human deaths worldwide annually (1). In the US alone, 555,500 Americans succumbed to the disease in

Correspondence to: Dr Karam F.A. Soliman, College of Pharmacy and Pharmaceutical Sciences, Room 104 Dyson Pharmacy Building, Florida A\&M University, Tallahassee, FL 32307, USA

E-mail: karam.soliman@famu.edu

Abbreviations: DTNB, 5,5-dithiobis-2-nitrobenzoic acid; EDTA, ethylene diamine tetraacetic acid; FBS, fetal bovine serum; $\mathrm{LC}_{50}$, lethal concentration at which $50 \%$ cells were killed; NADPH, nicotinamide adenosine dinucleotide phosphate; PBS, phosphatebuffered saline

Key words: ascorbic acid, hydrogen peroxide, glutathione, neuroblastoma cells
2002, which translates into more than 1,500 deaths daily (2). Recent reports indicate that cancer has become the number one cause of mortality in America, followed by coronary heart disease. Traditionally, the main therapeutic strategy in the fight against cancer is surgery and radiation. This approach is beneficial when the tumor is localized in a particular area in the body. However, in the case of disseminated cancers, the preferred approach to curb cancer cells is chemotherapy, where synthetic chemicals are used. Unfortunately, most of these chemotherapeutic drugs do not specifically target the tumors in the body and thus result in severe undesirable side-effects on the normal cells in cancer patients (3). Although natural products have recently been viewed as an alternative source of effective anticancer agents (4-11), they have yet to yield much success. Therefore, due to the differences in the internal and external tumor environments, it has become evident that a single chemotherapeutic agent does not suffice to kill tumor cells completely. A possible approach to this problem may be combination chemotherapy, where two or more compounds at non-toxic doses are employed to kill cancer cells selectively. Ascorbic acid is one of the naturally and abundantly occurring compounds ranging from 0.1 to $0.4 \mathrm{mM}$ in the cells (12). While its antioxidant properties are well known worldwide, its use as an effective anticancer substance is highly controversial (13). For instance, ascorbic acid has been reported to exhibit anticarcinogenic and antimutagenic activities $(14,15)$; however, its adverse effects have also been well documented $(16,17)$.

Studies have shown that under certain conditions, ascorbic acid functions both as an anti- and pro-oxidant in cells (18). Considering its safety at pharmacological doses $(19,20)$, ascorbic acid could be an ideal candidate for the combined treatment of malignant tumors. While the antioxidant activity of ascorbic acid is of little assistance in controlling tumor cell proliferation, its pro-oxidant action in the presence of certain compounds could help damage cancer cells (21). Initially, to explore the feasibility of this approach, we tested ascorbic acid in the presence of hydrogen peroxide $\left(\mathrm{H}_{2} \mathrm{O}_{2}\right)$ on murine neuroblastoma cells. Subsequently, total glutathione levels in these cells were evaluated.

\section{Materials and methods}

Cell culture. All routine chemicals used in this study were of analytical grade. The central nervous system derived murine 
neuroblastoma cell line, N2a (CCL-131) was purchased from the American Type Culture Collection (Rockville, MD, USA) and maintained as a monolayer culture in RPMI-1640 (modified) medium supplemented with $10 \%$ fetal bovine serum (FBS), L-glutamine $(2 \mathrm{mM})$, penicillin $(100 \mathrm{U} / \mathrm{ml})$, streptomycin $(100 \mu \mathrm{g} / \mathrm{ml})$ and amphotericin $\mathrm{B}(0.25 \mu \mathrm{g} / \mathrm{ml})$ in a $5 \% \mathrm{CO}_{2}$ incubator at $37^{\circ} \mathrm{C}$. Cell counts and cell viability were assessed using $0.4 \%$ trypan blue dye exclusion assay on a hemocytometer under a light microscope. Dye stained cells (blue) were counted as dead cells, while cells without dye were counted as viable cells. The actual cell numbers were determined by multiplying the diluted number of cells with the initial cell numbers. Cell viability exceeded $>90 \%$. Cells were diluted in complete RPMI medium and seeded in culture plates for the experiments.

Treatment of cells. Cells were seeded in flat bottom 96-well microtiter plates at a starting density of $2 \times 10^{4}$ cells per well in a total volume of $190 \mu \mathrm{l}$ growth medium supplemented with $10 \%$ regular FBS. The cells were allowed to adhere to wells in the incubator overnight. They were then treated (typically $60-70 \%$ confluent) with increasing concentrations of ascorbic acid (0.1-6 mM) or $\mathrm{H}_{2} \mathrm{O}_{2}(100-400 \mu \mathrm{M})$ in a final volume of $10 \mu \mathrm{l}$. Stock and working stocks of ascorbic acid or $\mathrm{H}_{2} \mathrm{O}_{2}$ were always prepared fresh in phosphate-buffered saline (PBS). In all the experiments, cells in the medium alone or cells in medium equal volumes of PBS served as the controls. These plates were incubated for $24 \mathrm{~h}$ continuously without further renewal of the growth medium in a $5 \% \mathrm{CO}_{2}$ in air at $37^{\circ} \mathrm{C}$ with the plates capped in the standard manner.

Evaluation of cytotoxicity. Cytotoxicity was evaluated by dye uptake assay using crystal violet, as previously described (5). As per this procedure, the cells were fixed with $0.25 \%$ glutaraldehyde, followed by gentle washing and stained with crystal violet dye. The dye was recovered and the optical density measurements were obtained at $540 \mathrm{~nm}$ in a plate reader. The average absorbance values of the controls were taken as $100 \%$ cell viability. From the treated and control absorbance values, the percentage of cells killed was determined by the following equation: [1-(T/C)] x100, where $\mathrm{T}$ is the average absorbance values of treated cells and $\mathrm{C}$ is the average absorbance values of control cells.

Estimation of cellular glutathione levels. N2a cells were treated with ascorbic acid $(0.4 \mathrm{mM})$ or $\mathrm{H}_{2} \mathrm{O}_{2}(100 \mu \mathrm{M})$ or with a combination of both, for $24 \mathrm{~h}$. Cellular glutathione was assayed according to the method described by Smith et al (22). In brief, following incubation, the cells were deproteinized with $2 \%$ 5-sulfosalicylic acid (10 $\mu \mathrm{l} /$ well) for $30 \mathrm{~min}$ at $37^{\circ} \mathrm{C}$, followed by the addition of $90 \mu \mathrm{l}$ of reaction mixture containing $0.416 \mathrm{mM}$ sodium ethylene diamine tetraacetic acid (EDTA), $0.416 \mathrm{mM}$ nicotinamide adenosine dinucleotide phosphate (NADPH), $0.835 \mathrm{mM}$ 5,5-dithiobis-2-nitrobenzoic acid (DTNB) and $0.083 \mathrm{mM}$ sodium phosphate buffer, $\mathrm{pH}$ 7.5. The mixture was incubated at $37^{\circ} \mathrm{C}$ for $30 \mathrm{~min}$. The absorbance was measured at $412 \mathrm{~nm}$ on a plate reader.

Statistical analysis. The experimental results were presented as the means \pm standard error mean (SEM). The data were analyzed for significance by one-way ANOVA and then

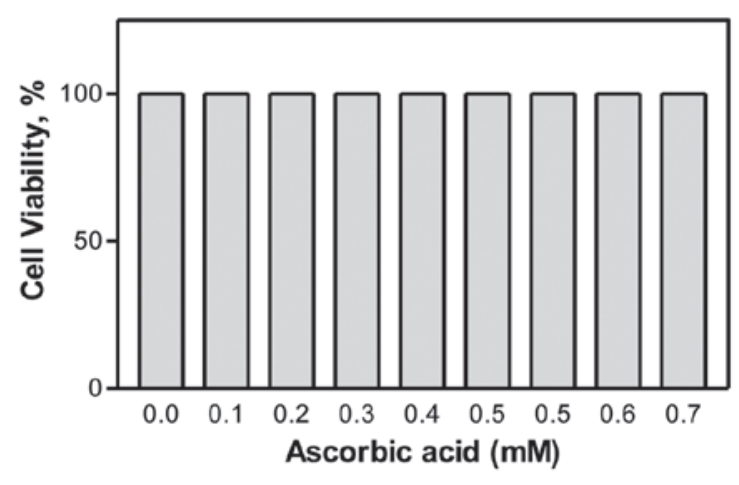

Figure 1. Effect of low ascorbic acid concentrations (physiological) on murine neuroblastoma cell viability. The cells with a starting density of $2 \times 10^{4}$ were treated with ascorbic acid for $24 \mathrm{~h}$. Data are represented as the means $\pm \mathrm{SD}\left(\mathrm{n}=12,{ }^{*} \mathrm{P}>0.05\right.$ denotes statistically significant differences vs. control).

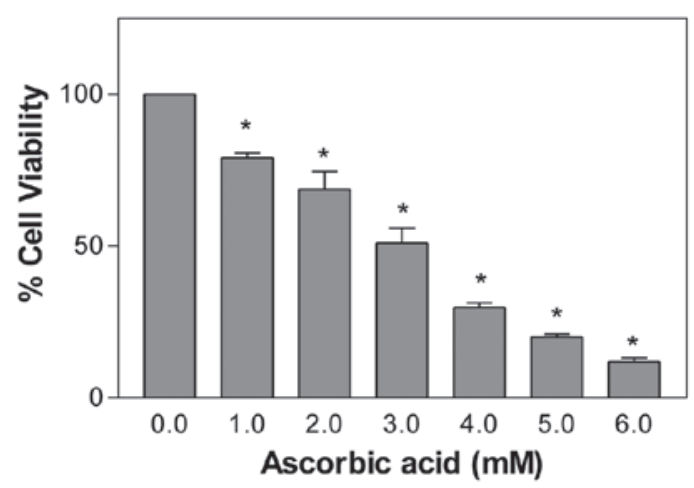

Figure 2. Effect of high ascorbic acid concentrations (pharmacological) on murine neuroblastoma cell viability. The cells with starting a density of $2 \times 10^{4}$ were treated with ascorbic acid for $24 \mathrm{~h}$. Data are represented as the means $\pm \mathrm{SD}$ $\left(\mathrm{n}=12,{ }^{*} \mathrm{P}<0.01\right.$ denotes statistically significant differences vs. control).

compared by Dunnett's multiple comparison tests using GraphPad Prism Software, Version 3.00 (San Diego, CA, USA). A P-value of $<0.05$ indicated a statistically significant difference. The lethal concentration at which $50 \%$ cells were killed $\left(\mathrm{LC}_{50}\right)$ values were determined from the graphs where both curves crossed (23).

\section{Results}

Biphasic activity of ascorbic acid on cells. In our preliminary studies, ascorbic acid at a concentration of 0.1-0.7 $\mathrm{mM}$ did not cause any cell death even after $24 \mathrm{~h}$ of exposure (Fig. 1). In the subsequent experiments, the concentrations of ascorbic acid were adjusted between 1 and $6 \mathrm{mM}$. Ascorbic acid was found to cause a significant $(\mathrm{P}<0.05, \mathrm{n}=12)$ dose-dependent decrease in the cell viability in comparison to the control. The percentage of cell viability $( \pm$ SEM) was $78 \pm 1.6,69 \pm 5.9,51 \pm 4.8,30 \pm 1.4$, $20 \pm 1.0$ and $12 \pm 1.2$ at $1,2,3,4,5$ and $6 \mathrm{mM}$ ascorbic acid, respectively (Fig. 1). The $\mathrm{LC}_{50}$ was found to be approximately $3.141 \mathrm{mM}$ after $24 \mathrm{~h}$ (Fig. 2). The non-toxicity of ascorbic acid at physiological concentrations and the dose-dependent cytotoxicity at pharmacological doses clearly demonstrate the biphasic behavior of ascorbic acid. 


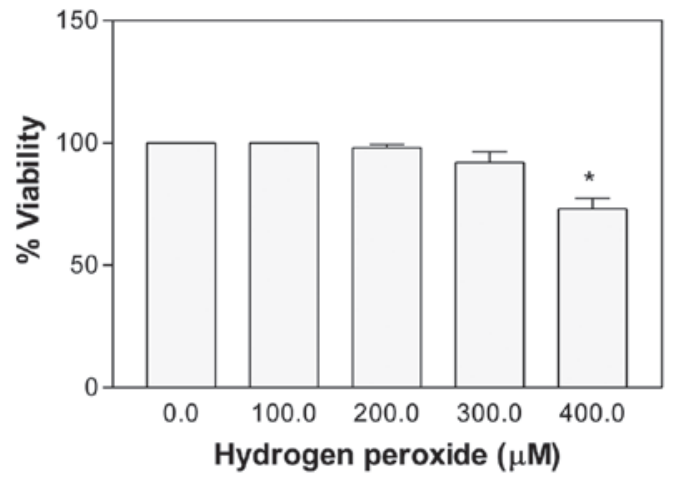

Figure 3. Effect of hydrogen peroxide $\left(\mathrm{H}_{2} \mathrm{O}_{2}\right)$ on murine neuroblastoma cell viability. The cells with a starting density of $2 \times 10^{4}$ were treated with $\mathrm{H}_{2} \mathrm{O}_{2}$ for $24 \mathrm{~h}$. Data are represented as the means $\pm \mathrm{SD}\left(\mathrm{n}=12,{ }^{*} \mathrm{P}<0.05\right.$ denotes statistically significant differences vs. control).

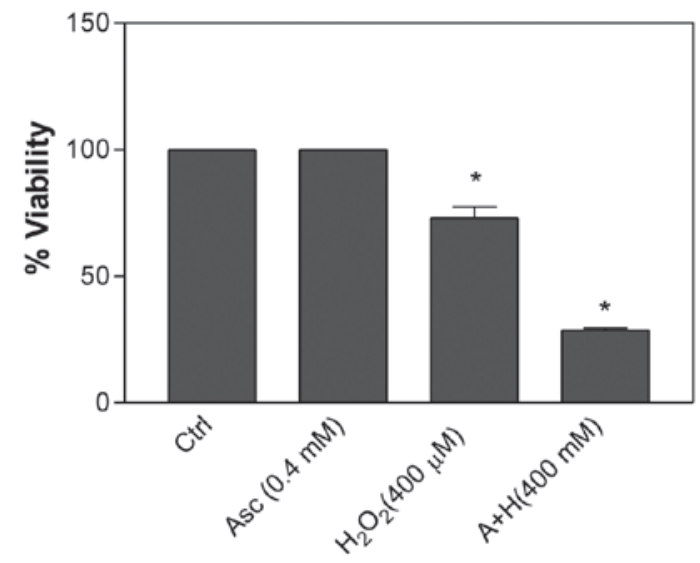

Figure 4. Effect of the combination of ascorbic acid $(0.4 \mathrm{mM})$ and $\mathrm{H}_{2} \mathrm{O}_{2}$ $(400 \mu \mathrm{M})$ on murine neuroblastoma cell viability. Cells were exposed for 24 h. Data are represented as the means $\pm S D\left(n=12,{ }^{*} P<0.01\right.$ denotes statistically significant differences vs. control).

Effect of $\mathrm{H}_{2} \mathrm{O}_{2}$ on cells. The role of $\mathrm{H}_{2} \mathrm{O}_{2}$ on cell viability was evaluated at different concentrations for $24 \mathrm{~h}$. It was found that in comparison to the untreated control, $\mathrm{H}_{2} \mathrm{O}_{2}$ did not cause a drastic decrease in cell viability at a dose of up to $300 \mu \mathrm{M}$ ( $\mathrm{P}>0.05, \mathrm{n}=12)$; however at $400 \mu \mathrm{M}$, there was significant $(\mathrm{P}<0.05, \mathrm{n}=12)$ cell death (Fig. 3). The percentage of cell viability $( \pm$ SEM) was $100 \pm 0.0,98 \pm 1.3,92 \pm 4.3$ and $73 \pm 4.3$ at $100,200,300$ and $400 \mu \mathrm{M} \mathrm{H}_{2} \mathrm{O}_{2}$, respectively. The estimated $\mathrm{LC}_{50}$ was found to be $>400 \mu \mathrm{M} \mathrm{H}_{2} \mathrm{O}_{2}$.

Combined effect of ascorbic acid and $\mathrm{H}_{2} \mathrm{O}_{2}$ on cell viability. The role of ascorbic acid was tested on cell viability in the presence of $\mathrm{H}_{2} \mathrm{O}_{2}$. The concentration of ascorbic acid was fixed at $0.4 \mathrm{mM}$, which represents the physiological concentration (12), and the cell viability was tested in the presence of $400 \mu \mathrm{M} \mathrm{H}_{2} \mathrm{O}_{2}$ for $24 \mathrm{~h}$. Ascorbic acid alone at a dose of $0.4 \mathrm{mM}$ did not induce cell death in comparison to the control. On the other hand, $\mathrm{H}_{2} \mathrm{O}_{2}$ alone at a dose of $400 \mu \mathrm{M}$ caused approximately $27 \%$ cell death. However, when combined with $0.4 \mathrm{mM}$ ascorbic acid, $\mathrm{H}_{2} \mathrm{O}_{2}$ at $400 \mu \mathrm{M}$ caused a sharp increase $(\mathrm{P}<0.05, \mathrm{n}=12)$ in cell death (Fig. 4). For instance, when both $\mathrm{H}_{2} \mathrm{O}_{2}$ and ascorbic acid were present together, cell

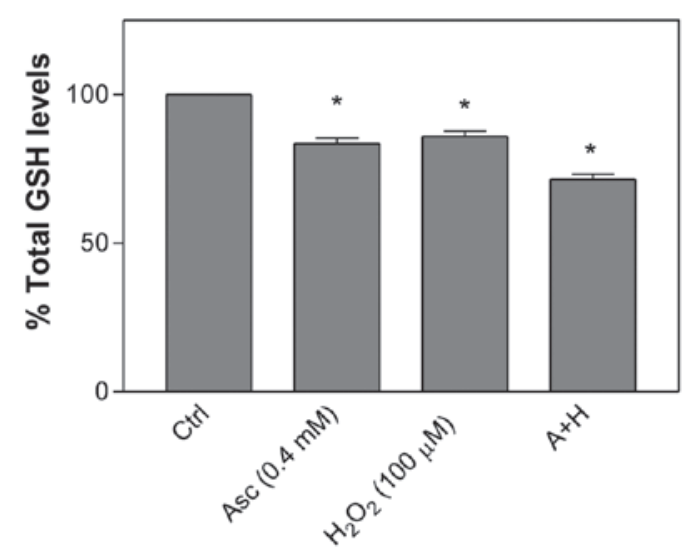

Figure 5. Effect of the combination of ascorbic acid $(0.4 \mathrm{mM})$ and $\mathrm{H}_{2} \mathrm{O}_{2}$ $(100 \mu \mathrm{M})$ on total glutathione levels in murine neuroblastoma cells. Cells were treated for $24 \mathrm{~h}$ and assayed for GSH levels. Data are represented as the means $\pm \mathrm{SD}\left(\mathrm{n}=12,{ }^{*} \mathrm{P}<0.05\right.$ denotes statistically significant differences vs. control).

death increased to $71 \%$. Decreasing the concentration of $\mathrm{H}_{2} \mathrm{O}_{2}$ $<300 \mu \mathrm{M}$ in the presence of $0.4 \mathrm{mM}$ ascorbic acid did not cause significant cell death (data not shown).

Effect of ascorbic acid and $\mathrm{H}_{2} \mathrm{O}_{2}$ on glutathione levels. Our results showed that ascorbic acid $(0.4 \mathrm{mM})$ and $\mathrm{H}_{2} \mathrm{O}_{2}(100 \mu \mathrm{M})$ alone at non-toxic doses caused a significant depletion in the total glutathione levels in the cells (Fig. 5) after $24 \mathrm{~h}$ of treatment. However, these levels decreased further when ascorbic acid and $\mathrm{H}_{2} \mathrm{O}_{2}$ were present together. Since we used glutathione reductase in the assay, the total glutathione measurements in our study represent both the oxidized (GSSG) and reduced form (GSH) of glutathione.

\section{Discussion}

Although chemotherapy is the best option for the treatment of disseminated tumors, the severe side-effects are the primary drawbacks of this approach. One of the novel strategies to circumvent the problem is to follow combination chemotherapy, where two or more drugs are tested simultaneously. Since this method is expected to achieve higher potency due to the synergistic interaction of chemical compounds, the major advantage is that it employs lower concentrations of individual components in the combined drugs. Thus, this procedure not only significantly decreases the undesirable side-effects, but it also prevents drug resistance by the tumor cells. In the present study, we investigated combining two compounds for an effective response on cells under in vitro conditions, using ascorbic acid and $\mathrm{H}_{2} \mathrm{O}_{2}$.

We observed that ascorbic acid exhibited biphasic behavior, where it was found to be inactive at physiological concentrations (Fig. 1) and cytotoxic at pharmacological doses (Fig. 2). The biphasic observations were consistent with earlier reports (20). At higher doses, ascorbic acid significantly killed cancer cells with an $\mathrm{LC}_{50}$ of $3.141 \mathrm{mM}$. The cytotoxicity results are in agreement with ones from previous studies (20). If the potency of ascorbic acid is increased further (i.e., if the $\mathrm{LC}_{50}$ is decreased) by mixing with another compound, this approach of the combination of drugs may become a more effective 
strategy to kill cancer cells selectively. In our experiments, we combined ascorbic acid at non-toxic doses with $\mathrm{H}_{2} \mathrm{O}_{2}$ and evaluated the cytotoxicity on the cells. While $\mathrm{H}_{2} \mathrm{O}_{2}$ itself did not cause severe toxicity to the cells (Fig. 3), the combination of ascorbic acid and $\mathrm{H}_{2} \mathrm{O}_{2}$ resulted in significantly higher rates of cell death (Fig. 4). Since the main function of ascorbic acid in the body is to act as an antioxidant against free radicals, the higher death rate due to the combination of ascorbic acid with $\mathrm{H}_{2} \mathrm{O}_{2}$ clearly suggests that ascorbic acid could also act as a pro-oxidizing agent, an observation consistent with previous studies (21).

Another very common antioxidant substance in the cells is glutathione. In our study, treatment with ascorbic acid alone was found to decrease the total glutathione levels of the cells. Although ascorbic acid is an effective antioxidant substance against oxidative stress in the cells, it was striking to observe that ascorbic acid at non-toxic doses depleted significant levels of glutathione (Fig. 5). This observation may suggest that ascorbic acid released certain oxidative species in the aqueous media. This speculation is consistent with earlier reports, in which the pro-oxidant action of ascorbic acid was shown to be the consequence of circumstantial conditions (21). On the other hand, $\mathrm{H}_{2} \mathrm{O}_{2}$ alone at non-toxic doses also caused a significant decrease in the total glutathione levels in the cells. These levels decreased further when ascorbic acid and $\mathrm{H}_{2} \mathrm{O}_{2}$ were added together to the cells (Fig. 5). The combination assay results were notable from the therapeutic point of view. For instance, it was shown that tumor cells have higher levels of glutathione than normal cells (24). The presence of elevated glutathione levels in malignant tumors often limits the effectiveness of chemotherapy (25). However, from our study, it is evident that by combining both ascorbic acid and $\mathrm{H}_{2} \mathrm{O}_{2}$ at non-toxic doses, a significant decrease in the glutathione levels in the cancer cells could be achieved, which may lead to effective death of cancer cells. In conclusion, considering the safety and the benefits of ascorbic acid, it can be an ideal candidate in combinational studies in clinical trials against malignant tumors.

\section{Acknowledgements}

This research project was supported by NCRR/RCMI G12RR03020, NIGMS/MBRS/SCORE GM08111 and HRSA SD34HP04018.

\section{References}

1. American Cancer Society Inc., Facts and Figures, 1998.

2. Jemal A, Thomas A, Murray A and Thun M: Cancer statistics, 2002. CA Cancer J Clin 52: 23-47, 2002.

3. Kamil N, Kamil S, Ahmed SP, Ashraf R, Khurram M and Ali MO: Toxic effects of multiple anticancer drugs on skin. Pak J Pharm Sci 23: 7-14, 2010.

4. Badisa RB, Chaudhuri SK, Pilarinou E, Rutkoski NJ, Hare H and Levenson CW: Licania michauxii prance root extract induces hsp 70 mRNA and necrotic cell death in cultured hepatoma and colon carcinoma cell lines. Cancer Lett 149: 61-68, 2000.
5. Badisa RB, Tzakou O, Couladis M and Pilarinou E: Cytotoxic activities of some Greek Labiatae herbs. Phytother Res 17: 472-476, 2003.

6. Badisa RB, Tzakou O, Couladis M and Pilarinou E: Cytotoxic activities of Salvia plants of Labiatae family. Pharm Biol 42: 640-645, 2004

7. Badisa RB, Badisa VLD, Watson DW, Pilarinou E and Walker EH: Cytotoxic activities of Snow Lotus filtrates against human cancer cell lines, and origin of active factors. Pharm Biol 42: 117-124, 2004.

8. Badisa RB, Couladis M, Tsortanidou V, Chaudhuri SK, Walker L, Pilarinou E, Santos-Guerra A and Francisco-Ortega J: Pharmacological activities of some Argyranthemum species growing in the Canary Islands. Phytother Res 18: 763-767, 2004.

9. Badisa RB, Lambert TAT, Ikediobi CO and Walker EH: Selective anticancer activity of pure licamichauxiioic-B acid in cultured cell lines. Pharm Biol 44: 141-145, 2006.

10. Badisa RB, Badisa VL, Walker EH and Latinwo LM: Potent cytotoxic activity of Saururus cernuus extract on human colon and breast carcinoma cultures under normoxic conditions. Anticancer 27: 189-193, 2007.

11. Badisa RB, Darling-Reed SF, Joseph P, Cooperwood JS Latinwo LM and Goodman CB: Selective cytotoxic activities of two novel synthetic drugs on human breast carcinoma MCF-7 cells. Anticancer Res 29: 2993-2996, 2009.

12. Zhang ZW, Abdullahi M and Farthing MJ: Effect of physiological concentrations of vitamin $\mathrm{C}$ on gastric cancer cells and Helicobacter pylori. Gut 50: 165-169, 2002.

13. Padayatty SJ and Levine M: Reevaluation of ascorbate in cancer treatment: emerging evidence, open minds and serendipity. J Am Coll Nutr 19: 423-425, 2000.

14. Greenblatt M: Brief communication: ascorbic acid blocking of aminopyrine nitrosation in NZO/Bl mice. J Natl Cancer Inst 50: 1055-1056, 1973.

15. Lo LW and Stich HF: The use of short-term tests to measure the preventive action of reducing agents on formation and activation of carcinogenic nitroso compounds. Mutat Res 57: 57-67, 1978.

16. Stich HF, Karim J, Koropatnick J and Lo L: Mutagenic action of ascorbic acid. Nature 260: 722-724, 1976.

17. Stich HF, Wei L and Whiting RF: Chromosome aberrations in mammalian cells exposed to vitamin $\mathrm{C}$ and multiple vitamin pills. Food Cosmet Toxicol 18: 497-501, 1980.

18. Kramarenko GG, Wilke WW, Dayal D, Buettner GR and Schafer FQ: Ascorbate enhances the toxicity of the photodynamic action of Verteporfin in HL-60 cells. Free Radic Biol Med 40: 1615-1627, 2006.

19. Levine M, Wang Y, Padayatty SJ and Morrow J: A new recommended dietary allowance of vitamin $\mathrm{C}$ for healthy young women Proc Natl Acad Sci USA 98: 9842-9846, 2001.

20. Chen Q, Espey MG, Krishna MC, Mitchell JB, Corpe CP, Buettner GR, Shacter E and Levine M: Pharmacalogic ascorbic acid concentrations selectively kill cancer cells: action as a pro-drug to deliver hydrogen peroxide to tissues. Proc Natl Acad Sci USA 102: 13604-13609, 2005.

21. Podmore ID, Griffiths HR, Herbert KE, Mistry N, Mistry P and Lunec J: Vitamin C exhibits pro-oxidant properties. Nature 392: $559,1998$.

22. Smith IK, Vierheller TL and Thorne CA: Assay of glutathione reductase in crude tissue homogenates using 5,5'-dithiobis(2nitrobenzoic acid). Anal Biochem 175: 408-413, 1988.

23. Ipsen $\mathrm{J}$ and Feigl P (eds): Bancroft's Introduction to Biostatistics. Harper\&Row, New York, p455, 1970.

24. Singhal RL and Vijayvargiya R: Studies on glutathione metabolism in ventral prostate and chemically induced prostatic carcinoma in rats. Biosci Rep 3: 241-253, 1983.

25. Wang T, Chen X, Schecter RL, Baruchel S, Alaoui-Jamali M, Melnychuk D and Batist G: Modulation of glutathione by a cysteine pro-drug enhances in vivo tumor response. J Pharmacol Exp Ther 276: 1169-1173, 1996. 